\title{
A CULTURE IN CONFLICT: \\ VIEWED THROUGH THE ART OF CONTEMPORARY WISCONSIN INDIANS \\ Patricia Stuhr
}

Prominent art educators have proposed that art can be perceived as a universal visual language. (E. Eisner, 1966; V. Lowenfeld, 1952; L. Chapman, 1978; F. Wachowiak, 1985) This perception of the universality of art as a visual language has been rejected by some art educators and philosophers. (J. McFee, \& R. Degge, 1977; F.G. Chalmers, 1980; D. Best, 1985) They contend that art cannot be perceived as a universal languaqe, but as many different visual languages. These visual languages are dependent on an in-depth analysis of the cultures in which they are produced and employed in order to be interpreted and understood. The production of art forms, their aesthetic values, their functions, and their goals are influenced and should be evaluated by the cultural group's historical traditions, values and beliefs. An anthropological view of a society's milieu can be an effective means of deciphering and understanding the art of different cultures and provide insights into one's own. Employing the hypothesis that art is not a universal language, but rather many different visual languages, an investigation of contemporary Wisconsin Indian Artists is being conducted.

The research undertaken involves the identification of contemporary Wisconsin visual artists. It explains the types of art they produce. It also investigates where, why and how they are producing these forms. Through this research, a cultural conflict has been exposed by the analysis of differing values and goals of Wisconsin Indian artists. This information may have applications towards the teaching of art in Indian and Anglo schools in the state.

This study was undertaken because of my experience in lecturing to Wisconsin Indian groups in the Wisconsin prison system. After lectures dealing with the art forms produced by North American Indians from almost every section of the United States except the Great Lakes, the question 
often arose as to whether there were any contemporary Wisconsin Indian artists. I replied that there were, but that only scant information on the subject could be found. From a recognition of this informational gap in Wisconsin art history this study was instigated.

The study follows the methodology of a field study. (G. Spindler, $\varepsilon$ L. Spindler, 1973; and T. Popkewitz, $\varepsilon$ R. Tabachnick, 1981) It is descriptive in nature, the description being collected by means of taped ethnographic interviews, photographs, and on-the-scene observations. These interviews take place throughout the state wherever the subjects live or are available for questioning. The interview is autocratic in model, meaning that the interviewer will act as an independent agent, and that the results will serve her purpose. (G. Spindler, $\varepsilon$ L. Spindler, 1973)

The first step in initiating my research was to compile a list of sources to contact for information on identification of practicing Wisconsin Indian artists. One-hundred and forty-four separate sources were written to. As informants returned the forms that I had supplied them with, the task of compiling and grouping the artists evolved. Preceding each interview with a practicing contemporary Wisconsin Indian artist, a letter was written. In the letter was an explanation of the purpose for the interview and a request for an appropriate time to set it up.

Upon visiting the artists for the interview gifts are presented, small tokens of my esteem for their talents and the knowledge which they are to share with me. It is a traditional Indian visitation procedure. The tape recorded interview consists of questions based on information about the individual artist's cultural and biographical background. The art work of the artist is described according to his/her interpretations. Photographs usually are taken after the interview, of the artist and his/her work if they allow it.

At present it appears that there are two major factions of contemporary Wisconsin Indian visual artists. This observation has been confirmed by Dr. Lurie, President of the Wisconsin Anthropological Society, who is currently employed by the County of Milwaukee Public Museum. During a phone conversation on February 13, 1984, she labelled these two factions 
the "Traditionalists" and the "modern" artists.

The "Traditionalist" artists produce art and craft forms based on the original types of art work and materials employed by Wisconsin Indians before the arrival of the Anglo. (P. Ritzenthaler, $\varepsilon$ R. Ritzenthaler, 1983) The original art forms are generally utilitarian (sometimes with great spiritual powers) and fashioned in the "old way". These art forms generally are made by individuals living on the Indian reservations or in the Indian communities. The art forms embody the values of the traditional, ethnic Indian community. According to Jessica Suhr, a sociologist, these values can be classified into three broad categories: spiritual, cultural, and social values. Spiritual values include the importance of religion, or spirituality, in everyday life; the significance of Indian ceremonies and healing processes; and the emphasis on unity with nature. Cultural values include the focus on sharing, the importance of "noninterference", the use of humor and the emphasis on a cyclical time concept. Social values include the importance of the extended family, the child, and the aged; and the Indian view of leadership as serving the people and being chosen on personal wisdom. (J. Suhr, 1983) Murray Wax, an anthropologist, includes the importance of close peer group relationships, and the rejection of competition at an individual level while accepting it at a group level. The goal of most of the "Traditionalist" artists in producing their art forms is to ensure the continuance of these values and the Indian ethnic community. (M. Wax, 1971)

The "Modern" artists use art forms and materials based largely on or influenced by the 20th century Anglo culture. These forms vary widely, but generally have lost their utilitarian purpose except aesthetic. The "Modern" artists show their cultural background influences in their work, but the materials can be novel and are not used in accordance with the more traditional Indian values. The values embodied in their work are generally those of the Anglo culture. The dominant values of the Anglo culture are still reflected in the quest for wealth, success, and upward mobility. (L. Chapman, 1978) Most "Modernist" Indian artists do not live on the reservations or in Indian communities, but in Anglo communities, 
generally urban, where they can find employment in their field of interest. The main goal of these artists in producing their art is to gain individual fame and monetary success in their field. These goals are in direct conflict with the goals of the ethnic traditional Indian communities. For this reason their art forms are not well accepted or appreciated by the Indians residing in the Indian communities or on the reservations. Because of the individual competitive nature of the "Modernist" artist, they often are conceived of as persons no longer integrated in the Indian community and to have "lost" their heritage.

The significance of this study may lie in the analysis of the conflict in values and goals between the two factions of the contemporary Wisconsin Indian visual artists. The identification and description of the practicing Indian artists may help the entire Indian community in our state by giving them a sense of their own worth and identity. For the Indians and Anglos in our state unfamiliar with the "Traditionalist" artist, it could be a corner stone on which to appreciate more fully part of the Indian cultural heritage, and to base criticism or appreciation of the "Modern" Indian artists on. To know the artifacts of the past gives one a sense of the future. (J. Highwater, 1976)

The discovery of how the Indian artists develop their skills and talents, whether it be learned cultural apprenticeship or acquired in private or public schools, may have significance for the teaching of art in Anglo and Indian schools. One might develop a new perspective on teaching methods by studying those employed by another culture. (R. Neperud, 1969) The full implications of this study will remain partially undetermined until all the data are collected.

\section{REFERENCES}

Best, D. (1985 Feeling and reason in the arts. George Allen \& Unwin. London.

Chalmer, F. G. (1980) Art education as ethnology. Studies in Art Education, 22 (3), 6-14. 
Chapman, L. H. (1978) Approaches to art in education. Harcourt, Brace, Jovanovich, New York.

Eisner, E. (1966) Readings in art education. Xerox College Publishing. Lexington, Massachusetts/Toronto.

Highwater, J. (1976) Song from the earth. New York Graphic Society. Boston.

Lowenfeld, V. (1951) Creative and mental growth. The MacMillian Company. New York.

McFee, J. K. \& Degge, R. (1977) Art, culture and environment. Wadsworth Publishing Co., Inc. New York .

Neperud, R. W. (1969, Winter) Visual arts instruction in primitive societiesits implications for art education. Studies in Art Education, 10, pp. 1224.

Popkewitz, T. S., Tabachnick, R. B. (Eds.). (1981) The study of schoolingField based methodologies in educational research and evaluation. Praeger Publishers. New York. Ritzenthaler, P. \& Ritzenthaler, R. E. (1983) The Woodland Indians of the western Great Lakes. Milwaukee Public Museum. Milwaukee, Wisconsin. Spindler, G. \& Spindler, L. (Eds.). (1973) Case studies in education and culture. Holt, Rinehart, and Winston. New York.

Suhr, J. (1983) Native American values and the application of directive therapy to value conflict. (Master's Thesis, University of Wisconsin Milwaukee.).

Wachowiak, F. (1985) Emphasis art. (4th Ed.). Harper and Row, Publishers. New York. Wax, M. (1971) Indian American unity and diversity. Prentice-Hall, Inc., New Jersey. 